GOSPODARKA SUROWCAMI MINERALNYMI - MINERAL RESOURCES MANAGEMENT

2016

Volume 32

Issue 3

Pages 5-22

DOI 10.1515/gospo-2016-0024

\title{
Trends in the consumption of hard coal in Polish households compared to EU households
}

\author{
Introduction
}

One of the primary fuels used by European households for heating purposes is hard coal. This fuel is popular especially in those countries that had or still have their own coal mining industry. However, concern for the environment on a global scale means that in many countries the consumption of this fuel is reduced for the benefit of other energy sources, such as natural gas or renewables.

In December of 2015, Paris hosted the UN Climate Convention (COP21), in which the participating states pledged a further reduction of $\mathrm{CO}_{2}$ emissions. Specific numbers of $\mathrm{CO}_{2}$ emissions reduction were presented, together with plans to achieve them, which will cause a fundamental impact on the level of energy consumption, as well as on the fuel and energy mix. Considering the fact that most national plans provide for increasing the use of renewable energy sources and nuclear energy, this will in turn contribute to reducing the use of fossil fuels.

Due to the important role of hard coal in the Polish residential sector, the aim of this article is to trace the changes that have occurred in the use of this fuel in the European Union and in Poland. The analysis covered a period of twenty-five years: from 1990 to 2014.

In order to eliminate statistical differences in the aggregated data for the EU and its individual Member States, the article uses official European statistics. According to the Eurostat

* Ph.D. Eng., The Mineral and Energy Economy Research Institute, Polish Academy of Sciences, Krakow, Poland; e-mail: kszlugaj@min-pan.krakow.pl 
methodology (Eurostat - Relationships...) hard coal (in total) is understood as: anthracite, coking coal, other bituminous and sub-bituminous coal. When discussing specific countries, their national statistics were used.

\section{Characteristics of households in the EU and in Poland}

As of January 1, 2015, the European Union had a population of 508.45 million people (Eurostat - Population...), of which 7\% was the share of the population in Poland (38.01 million people). The Polish gross domestic product (Eurostat - Economy...) reached EUR 427.7 billion (at current prices) and its share in the total GDP of all the Member States amounted to 3\% (EU28 - EUR 14,625.4 billion). The total housing stock of all the EU countries accounted for 236 million homes and apartments (data for 2013) (Fig. 1a), with largest share of Germany (17\%), followed by Italy, France and Great Britain (12\% each). Poland, with residential resources amounting to almost 14 million dwellings, was sixth in this list Of all the EU countries, Poland had the lowest number of dwellings per 1,000 inhabitants (360 pcs.), only Slovakia had a similar amount (370 pcs.), while Estonia has the largest number (1082 pcs.) (Fig. 1b).

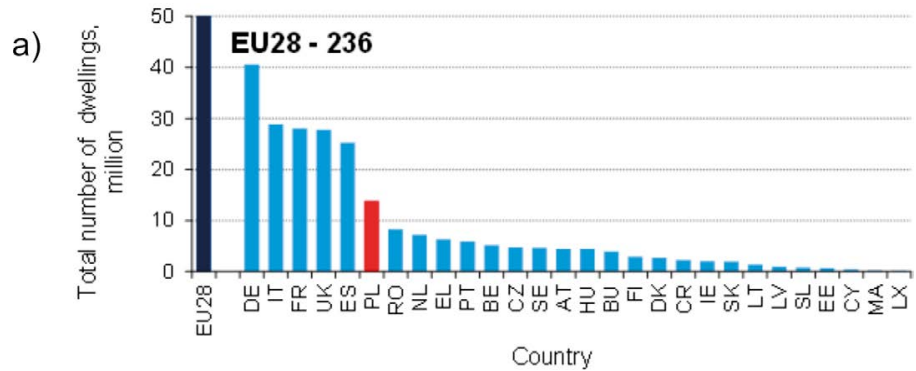

b)

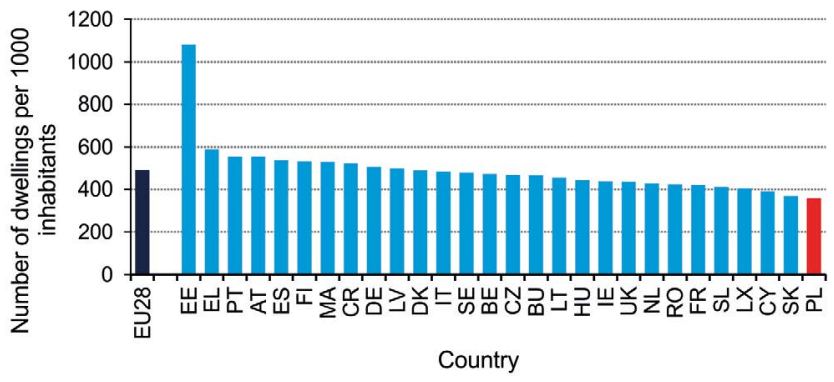

Fig. 1. Stock of dwellings in countries of the European Union, date: 2013

a) total, b) number of dwellings/1000 inhabitants

Source: own study results based on (Pittini et al. 2015)

Rys. 1. Zasoby mieszkaniowe w państwach Unii Europejskiej, rok 2013

a) ogółem, b) szt./1000 mieszkańców

Źródło: opracowanie własne na podst. (Pittini i in. 2015) 
In terms of the degree of urbanization throughout the European Union, most people live in rural areas (Fig. 2): in 2005 their share was $46 \%$, and ten years later it dropped to $42 \%$. In comparison, this number is lower in Poland and increased from $22 \%$ (in 2005) to $28 \%$ (2014). This increase can be linked to an increase in private construction, especially in rural areas, which resulted in the migration of the population from cities (mainly from large urban areas) to the countryside. This migration is well illustrated in Fig. 3: back in 2005 the share of homes in rural areas was $31 \%$, while in 2014 it increased by 4 percentage points. In contrast, multi-apartment buildings, both in Poland and throughout the European Union, mostly concentrated in cities: in 2005 their share was about 1/3, and in 2015 fell to $25 \%$.

According to the Eurostat methodology (Eurostat - Glossary...) when discussing the degree of urbanization of a particular country, urban areas are distinguished as: cities and
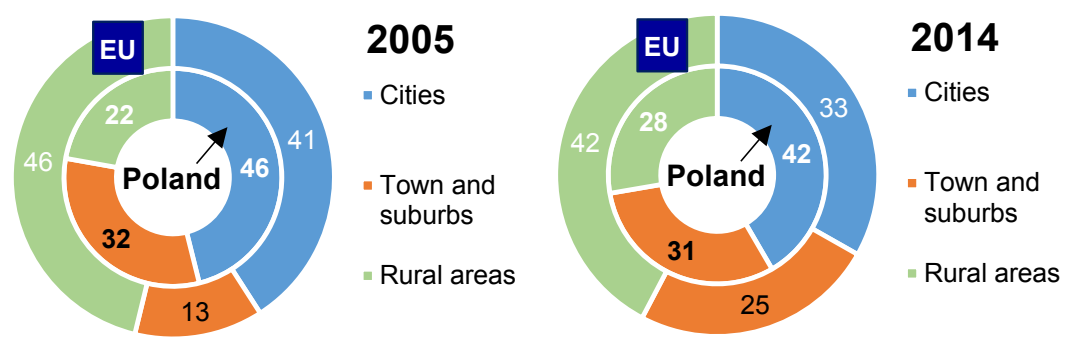

Fig. 2. Distribution of population by degree of urbanization, comparison of the years 2005 and 2014 Source: own study based on (Eurostat - Distribution...)

Rys. 2. Podział ludności według stopnia urbanizacji, porównanie lat 2005 i 2014

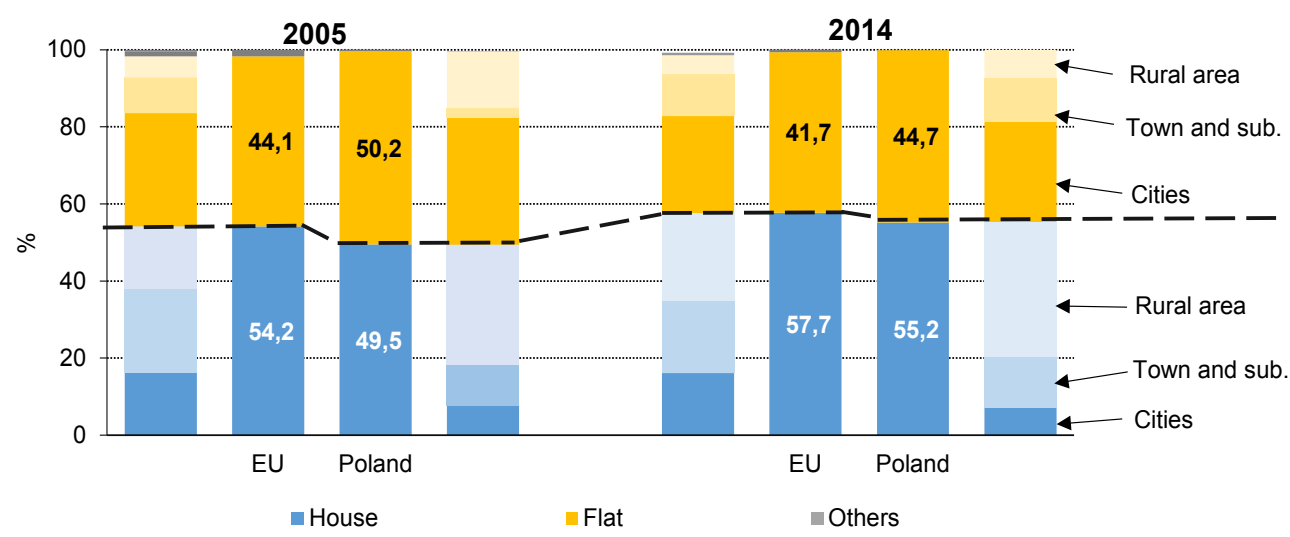

Fig. 3. Comparison of structure of dwellings in EU and Poland by the buildings location Source: own study based on (Eurostat - Housing ...)

Rys. 3. Porównanie struktury mieszkań w UE i Polsce wg lokalizacji budynku 
towns/suburbs. Cities address areas in which at least $50 \%$ of the population lives in high-density groups and areas understood as towns and suburbs - less than $50 \%$ of the population lives in such groups. Rural areas refer to the population that lives outside urban centers.

\section{Consumption of hard coal in the European Union compared to other energy sources}

Throughout the European Union hard coal holds an important place in the structure of primary energy consumption. The size and structure of primary energy consumption depends on many factors. These two elements are influenced by the following factors, among others: the economic situation of the country, adopted energy policy, efficiency of energy use, atmospheric conditions, as well as the availability and price of the particular energy carrier.

In the years 1990-2014 primary energy consumption in the European Union (calculated for all 28 Member States) has changed between 1507 (2014) and 1722 (in 2006) million toe (Fig. 4). According to the directive (Council Directive 2013/12/EU) by 2020, energy consumption in the Union as a whole is expected to be no more than 1483 Mtoe of primary energy. In 2014, the total primary energy consumption in the EU28 reached the lowest level since 1990 and was higher than assumed in the mentioned Directive by only about 24 million toe (2\%). Between 2014 and 1990 the average annual rate of decline in consumption of this energy amounted to $0.2 \%$.

The European Union's actions to protect the climate caused a reduction in the consumption of coal. In the early 1990s, it was over 300 million toe, at the end of the decade fell to 220 million toe, after 2008 it did not exceed the level of 200, and in 2014 it amounted to 179 million toe (Fig. 4). Between 1990 and 2014 the consumption of hard coal decreased

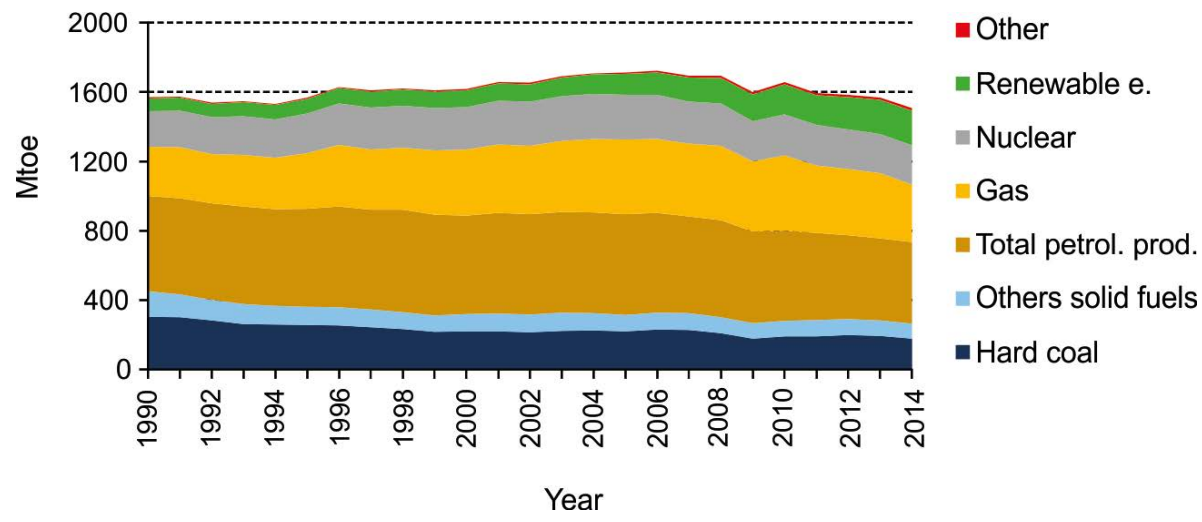

Fig. 4. Primary energy consumption by fuels in EU28, years 1990-2014 Source: own study based on (Eurostat - Complete...) 
by $41 \%$ (a decrease of 126 million toe), and the average rate of decline in the consumption of this fuel amounted to $-2.1 \%$.

Total petroleum products have the largest share in the structure of consumption of primary energy: $30-36 \%$. Gas (defined as natural gas and its derivatives) is in second place with the share remaining at a similar level of $13-15 \%$. The consumption of renewable energy sources is steadily increasing. In 1990 it was only 72 million toe (5\% share) while in 2014 it increased almost threefold. The share of renewable energy sources accounted for $13 \%$ of total primary energy consumption. That increase in the share of renewable energy involves, among others, the implementation of the adopted EU strategy on, among others, climate change and sustainable energy use.

\section{Legal regulations in the European Union at a glance}

The main element influencing the consumption of energy in the European Union - including hard coal used by customers from the residential sector - are regulations related especially to climate protection. Many legal acts introduced by the European Parliament overlap one another, are derived from other acts, or replace them. They are divided into several thematic areas, among which include: widely understood environmental protection, energy efficiency, construction, etc. EU legal standards are then implemented into the law of the particular member states.

There are six different sources of law in the European Union, which include (Implementacja prawa...2013): primary law (the Treaties and the Charter of Fundamental Rights), secondary legislation (regulations, directives and decisions), the general principles of EU law and the judgments of the European Constitutional Court. All sources of EU law are just as legally binding, although there is a hierarchy between them (formal in nature rather than actual).

In view of the increasing emission of greenhouse gases, global action was taken to minimize the impact of human activities on climate change. Taking the time span analyzed in the article into account, it should be mentioned that in 1991, the representatives of the European Community participated in the United Nations Framework Convention on Climate Change. Although the convention has contributed to the strengthening of the world community's awareness on issues related to climate change (e.g. it set out the principle of common but differentiated responsibility principles), it did not contain specific commitments of individual countries on the reduction of greenhouse gas emissions. It was not until the Kyoto Protocol adopted at the end of 1997, in which the participating countries made commitments on measures to reduce emissions after 2000 for industrialized countries. In the case of the European Community, the Kyoto Protocol was approved in 2002 by a Council Decision (Council Decision 2002/358/EC). In the aforementioned Protocol, specific commitments on emission limitations and reductions of greenhouse gases were presented and the year 1990 was adopted as the base year. Each of the Member States is granted the appropriate emission 
limits by the relevant legal acts (e.g. Commission Decision 2006/944/EC, Commission Decision 2010/778/EU). The Kyoto Protocol expired on December 31, 2012.

One of the elements for the reduction of carbon dioxide emissions is to improve energy efficiency. In 1991, by the Council's Decision (Council Decision 91/565/EEC), the Council of Ministers of the Environment and Energy adopted a program called SAVE to promote energy efficiency in member states. It drew attention to the residential sector, which then absorbed almost $40 \%$ of the final energy consumption in the Community. Bearing the development aspect of the sector in mind, it was feared that by potentially increased energy consumption, $\mathrm{CO}_{2}$ emissions would also increase. Improving energy efficiency was supposed to be carried out by: the legalization of the energy effectiveness of buildings, billing of heating, air-conditioning and domestic hot water on the basis of actual consumption; financing investments aimed at improving energy efficiency in the public sector by third parties, thermal insulation of new buildings, a periodic inspection of central heating boilers, energy diagnostics in companies with high energy consumption.

The consumption of hard coal in the European Union was significantly influenced by, among others, the IPPC Directive - Integrated Pollution Prevention and Control of 1996 (Council Directive 96/61/EC) on integrated pollution prevention and control. For technical installations in certain fields of human activity, which are considered particularly burdensome for the environment, this directive imposed the need to obtain the so-called integrated permit for technological installations operating in the EU. It especially regards installations in the industry (including fuel and energy, chemical, mineral or metallurgical), agriculture (slaughterhouses, dairies, tanneries) and related to municipal waste management. Conditions of the obtained permits for this category of industrial activity are to conform to the rules of the best available technologies which are to be determined in accordance with the of BAT - [Best Available Techniques] standards.

Climate and energy packages should also be mentioned. The first package (COM(2008) 30 final) was adopted by the European Union in January 2008. It set three objectives: reducing greenhouse gas emissions (by $20 \%$ ), increasing the share of renewable energy (up to $20 \%$ ) and improving energy efficiency (by $20 \%$ ). This package is often called " $3 \times 20$ " or "20-20-20". In the second climate package from January 2014 (COM(2014) 15 final), the European Commission has proposed that by 2030, the goal of reducing GHG emissions compared to 1990 should be increased not by the previous $20 \%$ but by $40 \%$. By 2030 the sector covered by the EU emissions trading scheme will have to reduce greenhouse gas emissions compared to 2005 levels by $43 \%$, and the sector not covered by the scheme - by $30 \%$. The share of renewable energy is expected to increase by at least $27 \%$.

In 2001, The Clean Air for Europe (CAFE) Programme was presented: Towards a Thematic Strategy for Air Quality (COM/2001/0245 final), in which it was decided to take action to reduce emissions of five atmospheric air pollutants $\left(\mathrm{SO}_{2}, \mathrm{NOx}, \mathrm{VOCs}\right.$, ammonia and PM2.5). As part of this program, a number of thematic strategies were developed in subsequent years: for example, the Thematic Strategy of air pollution (COM(2005) 446 final) paid attention to the IPPC Directive so that it also covers objects with a combustion power 
of less than $50 \mathrm{MW}_{\text {th }}$ (Smaller Combustion Plants, also called Smaller Combustion Installations - SCIs). However, in 2008 the Directive (Directive 2008/50/EC) - often called the "CAFE Directive" - established targets for reducing emissions of the aforementioned pollutants and set specific permitted levels of pollution. The CAFE Directive also introduced new mechanisms for managing air quality in zones and agglomerations and obliged the Member States to designate responsible authorities and entities.

The Europe 2020 Programme (Programme Europe...) adopted by the European Council in 2010 is the EU's strategy for economic growth for the period from 2010 to 2020 . The aim of this strategy is to achieve, among others, sustainable growth by building a more competitive low-carbon economy, based on rational and efficient use of natural resources, reduction of greenhouse gas emissions and biodiversity conservation. Among others, it is projected to intensify efforts to develop new, environmentally friendly technologies and improve conditions for the development of micro-, small- and medium-sized enterprises. For example, in the case of Poland, the renewable energy share in the overall energy consumption by 2020 should increase to $15 \%$ and the primary energy consumption is to be reduced to the level of 93 million toe.

In order to increase energy efficiency by $20 \%$, the EU Energy Efficiency Directive (Directive 2012/27/EU) was introduced. It promotes low-carbon economy, high-efficiency co-generation, efficient district heating and cooling systems and increasing the share of renewable energy. One element of achieving low-carbon economy for the residential sector is the use of high-performance solid fuel boilers that emit low pollution load. The EU Commission Regulation (Commission Regulation 2015/1189) set out requirements for the placing on the market and the use of solid fuel boilers with a nominal output of $500 \mathrm{~kW}$ or less. For example, as of January 1, 2020, the seasonal energy efficiency of heating premises for solid fuel boilers with a nominal heat output of $20 \mathrm{~kW}$ or less cannot be less than $75 \%$, and for power exceeding $20 \mathrm{~kW}$ - cannot be less than $77 \%$. In the case of boilers with automatic fuel feeding, particulate emissions for the seasonal heating of premises must not exceed $40 \mathrm{mg} / \mathrm{m}^{3}$, and boilers with manual loading of fuel $-60 \mathrm{mg} / \mathrm{m}^{3}$. These values correspond to the criteria of the EU eco labelling characterizing boilers with the highest 5th grade. In the case of Poland, they must meet the requirements of the PN-EN 303-5: 2012 standard.

The programs and EU directives quoted above do not fully cover the issues discussed. Instead, they were to show that the European Union has, for many years, taken specific steps to protect the climate, which then influence the consumption of coal in particular years. The subject of the impact of EU legislation on the consumption of energy and their production, power generation, as well as on waste storage, broadly defined environmental protection and the associated environmental education, has been the subject of many scientific publications for years, e.g. Lorenz (1999), Blaschke (ed. 2003), Klojzy-Karczmarczyk and Mazurek (2009, 2013), Mudgal et al. (2009), Pawul and Sobczyk (2011), Grudziński (2012, 2013), Gawlik (ed.) 2013, Olkuski (2013), Kubica (2013, 2015), Kamiński (2014), Szczerbowski (2015). 


\section{Consumption of hard coal in the residential sector}

Throughout the European Union the residential sector is not as important a consumer of hard coal, as it is in Poland. Although hard coal consumption in the EU28 in this sector in the years 1990 to 2014 varied from 6.5 (2000) to 15.8 (1991) Mtoe, its share in the overall consumption of fuel was usually maintained at around $3-5 \%$ (Fig. 5).
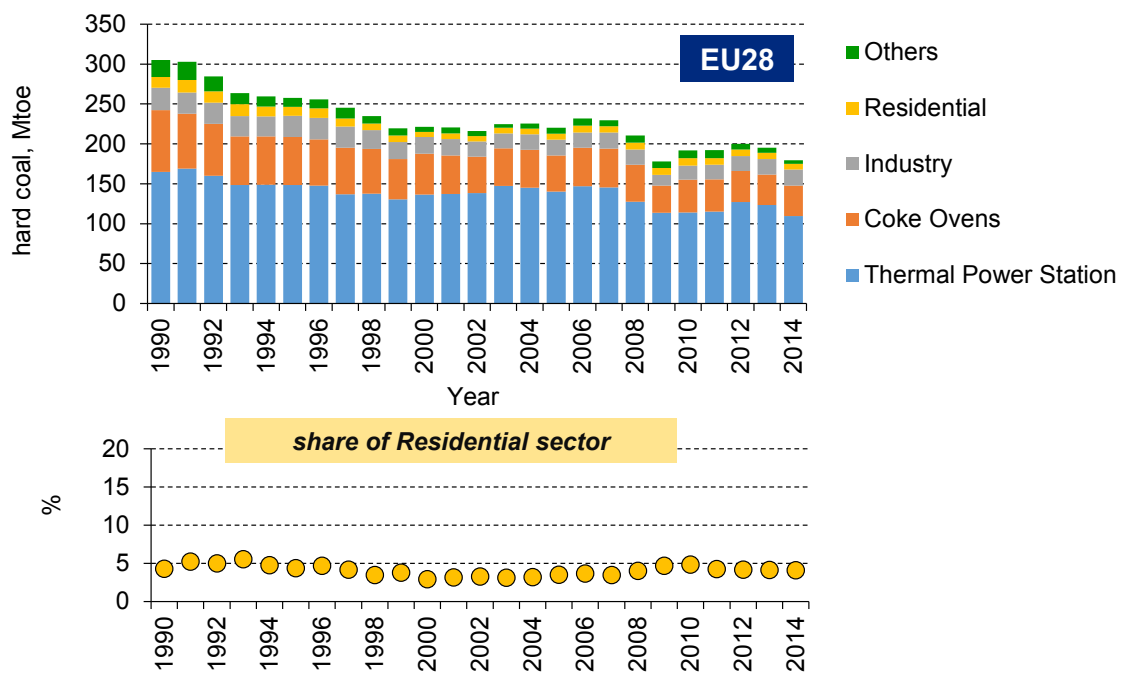

Fig. 5. Hard coal consumption by sectors in EU28 Source: own study based on (Eurostat - Complete...)

Rys. 5. Zużycie węgla kamiennego według grup odbiorców w UE28

The structure of hard coal consumption by the residential sector in the countries forming the EU28 over the years 1990-2014 is presented in Figure 6. The data has been ranked in descending order of consumption from the year 1990. The countries in the lead are those which have their own coal mines (Fig. 7). Apart from Poland (with a 50\% share in 1990) these countries include: Great Britain (18\%), Spain, Belgium and France ( $8 \%$ each). Twenty-five years later, Poland has remained at the forefront (with share as high as $84 \%$ ), and was followed by: Spain (11\%), Romania (5\%), Great Britain (4\%), Italy and Ireland (3\% each). The changing fuel mix, closing of mines or gradual extinction of coal mining, environmental policy of the individual countries meant that coal has lost its position in some of them.

The structure of major hard coal producers in the European Union has been consistent for years, with Poland and Great Britain in the first and second place respectively. By 2008, Germany was the third producer, but since 2009 its place has been taken over by the Czech Republic (Fig. 7). The shape of this structure was influenced in a major way 


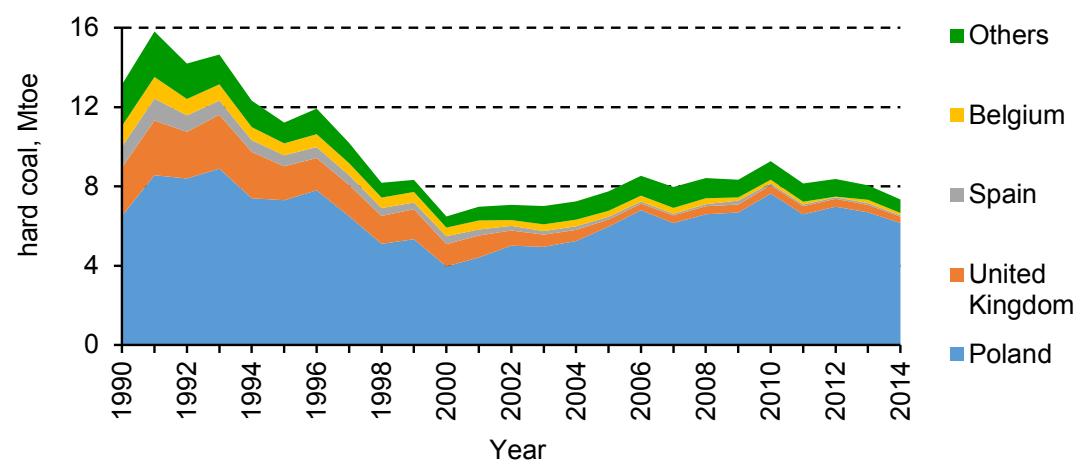

Fig. 6. Hard coal consumption in Residential sector by country, years 1990-2014 Source: own study based on (Eurostat - Complete...)

Rys. 6. Zużycie węgla kamiennego przez sector mieszkalny według państw, lata 1990-2014

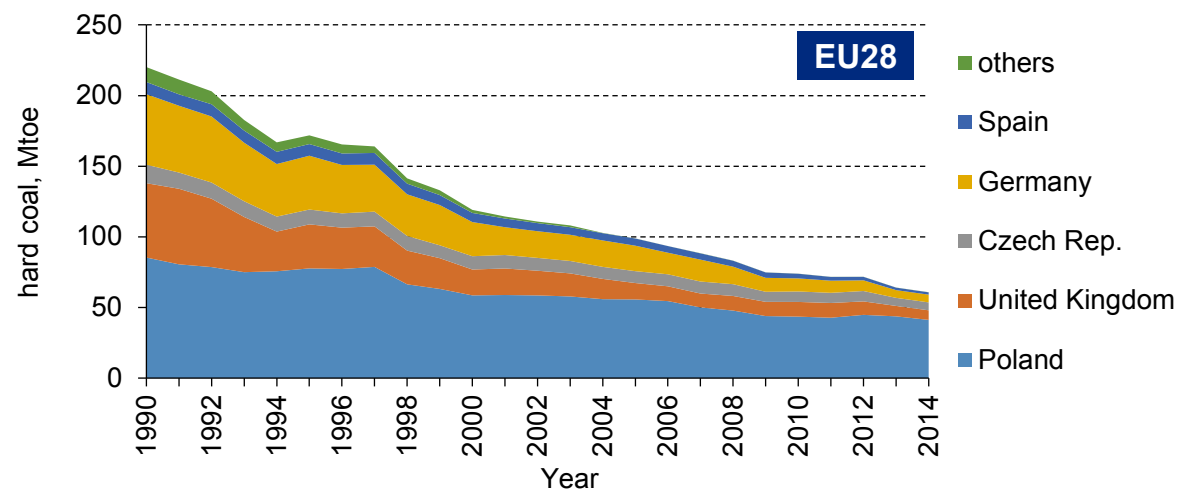

Fig. 7. Major producers of hard coal in EU28, years 1990-2014 Source: own study based on (Eurostat - Complete...)

Rys. 7. Główni producenci węgla kamiennego w UE28, lata 1990-2014

not only by global trends, but also by individual policy of the states. The process of closing mines in Great Britain started in the second half of the 1980s and the gradual extinction of hard coal mining in Germany meant that these countries ceased to play an important role in the production of this raw material in the European Union. In the years 1990-2014, the average annual rate of decline in hard coal production in these countries amounted to $-8 \%$ each, in the case of Poland: $-3 \%$, and for the entire EU28 area: $-5 \%$. The gradual decrease of hard coal production in Great Britain and Germany resulted in the fact that during the analyzed 25 years, Poland's share in the structure of hard coal producers increased from the initial 39\% (in 1990) to 68\% (in 2014). 


\section{Comparison of hard coal consumption in the residential sector in Poland and Great Britain}

Poland and Great Britain are interesting cases among the EU member states. In 1990, these countries were in the forefront both in terms of production as well as the consumption of hard coal by the housing sector, and twenty-five years later, only Poland remained in this position.

Poland

During the years 1990-2014, the Polish residential sector consumed from 50 to $84 \%$ of the tonnage of hard coal burned in the EU, i.e. 4.0-8.9 million toe (with its participation in domestic consumption ratio of $9-16 \%$ ). In terms of the structure of consumers this sector following thermal power plants and coking plants - is the third most important consumer of hard coal in Poland (Fig. 8).

Due to the easy availability (in terms of distribution) of domestic hard coal, both in Poland and in the UK, it has been a popular fuel used in households for decades. Although the consumption of hard coal in Poland fell by 6\% between 1990 and 2014, it has still exceeded 6 million toe and dominated in the structure of the main energy carriers (Fig. 9a). The per capita consumption of hard coal remained at a similar level of 0.2 toe. The second carrier was the derived heat: compared with 1990, its consumption decreased by $1 / 3$ and reached 3.9 million toe, and its share fell from 32 to $21 \%$. The per capita consumption of derived heat
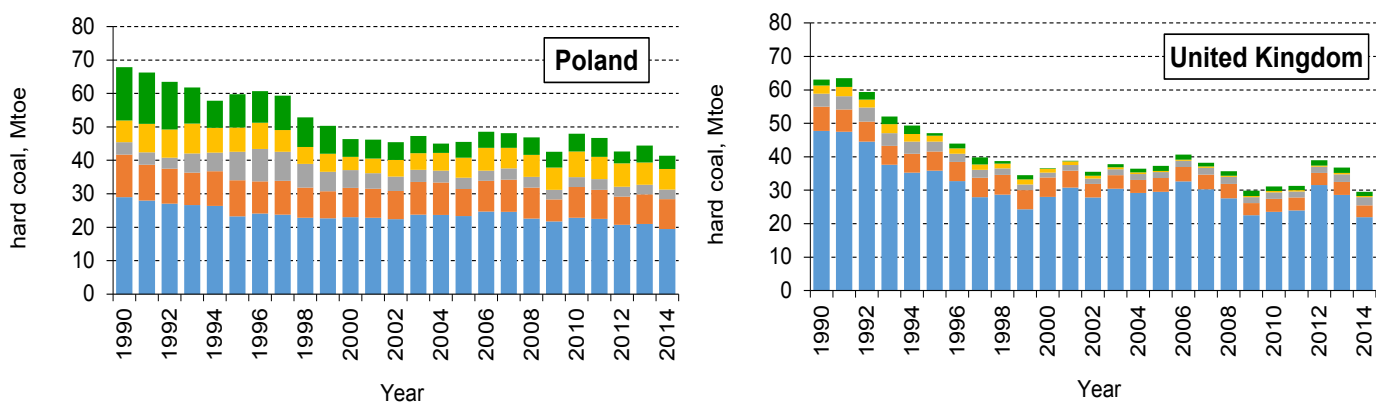

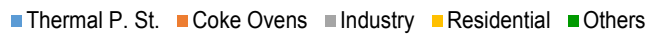

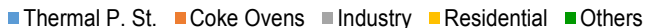
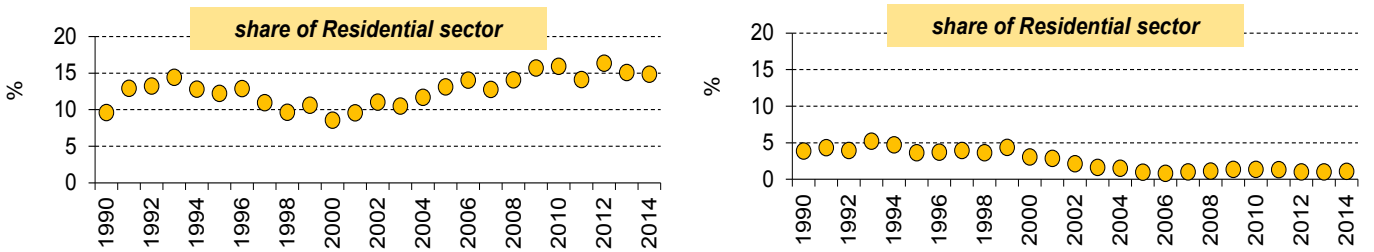

Fig. 8. Hard coal consumption by sectors; a) Poland, b) United Kingdom Source: own study based on (Eurostat - Complete...)

Rys. 8. Zużycie węgla kamiennego według grup odbiorców; a) Polska, b) Wielka Brytania 


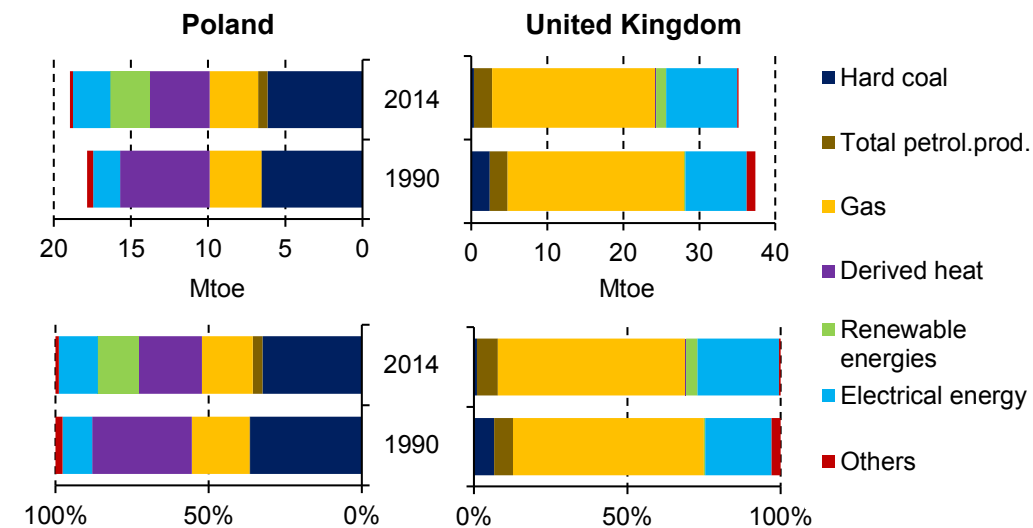

Fig. 9. Residential sector-consumption of energy sources in Poland (a) and The United Kingdom (b) Source: own study based on (Eurostat - Complete...)

Rys. 9. Sektor mieszkaniowy - zużycie nośników energii w Polsce i Wielkiej Brytanii

decreased from 0.2 (in 1990) to 0.1 toe per capita (in 2014). The third energy carrier in the Polish residential sector in 2014 were the renewable energy sources: their share was over $13 \%$, while consumption exceeded 2.5 million toe in per capita - almost 0.1 toe per capita (in 1990 RES consumption did not occur).

Over the years 1990-2014 housing resources in Poland increased by $27 \%$ and at the end of 2014 amounted to 13.98 million units (according to national data (GUS [Central Statistics Office] - Rocznik statystyczny... 1991-2015). From the viewpoint of the heat source, premises equipped with a central heating system prevail in Poland. In 1990, out of 11.02 million inhabited dwellings, $64 \%$ were heated by a central heating system, by 2014 their number increased by 4.39 million units, and its share increased to $82 \%$ (data: GUS - Rocznik statystyczny... 1991-2015, GUS - BDL). Most apartments equipped with central heating system are located in cities, their share increased from 74 (in 1990) to 87\% (in 2014). This is due to the fact that in larger urban centers, in which multi-apartment buildings dominate, a popular source of heat is the district heat from large heat and power plants or district heating plants.

In terms of techniques used for heating in Poland, appliances burning solid fuels (mainly hard coal) and using the district heat have been dominating for years. In the last several years, the share of fossil fuels fell slightly from 48 (in 2002) to $46 \%$ (in 2012) and the share of households heated by district heat remains at a similar level of $42-43 \%$ (GUS - Use of Energy... 2012, 2014). In individual central heating: boilers, solid fuels, (mainly hard coal) and natural gas are most commonly used. The share of solid fuel boilers increased from 28 (in 2002) to 35\% (in 2012) and the share of boilers for natural gas increased from 6 to $9 \%$. Due to the carried out modernization (often supported by country's budget or EU funds), both in the case of solid fuels and natural gas, the share of dual-purpose boilers increased: from 12 (in 2002) to $20 \%$ (in 2012) in the case of the former, and in gas - from 6 to $9 \%$. 
Meanwhile, the share of old stoves and solid fuel kitchens decreased: from 20 (in 2002) to $9 \%$ (in 2012). In 2002, the number of dwellings heated by old furnaces amounted to 2.45 million (GUS - Warunki... 2003), and in 2011 - decreased by 0.37 million apartments (GUS - Warunki... 2014). The average age of equipment (data for 2012 according to the GUS - Zużycie energii... 2014) used for heating by burning these two energy carriers in most cases was $8-10$ years, and in the case of traditional heating devices (mainly stoves and solid-fuel kitchens) - ca. 24 years.

In terms of the number of households in 2002, 5.7 million dwellings consumed coal, and in 2012 their number dropped to 5.5 million (GUS - Zużycie energii... 2012, 2014). The average consumption per household has fallen from 3.0 to 2.9 tons of coal.

\section{Great Britain}

In the UK, hard coal was the third carrier of energy in 1990 (Fig. 9b): consumption stood at 2.4 toe ( 0.04 toe per capita), and its share was $7 \%$. In the two compared years, gas consumption (over $60 \%$ share) dominated in the British residential sector. Relative to 1990, it decreased by $6 \%$ (by 1.7 toe) and in 2014 amounted to 21.5 million toe.

Despite the growth of the housing stock in the UK (between 1990 and 2012 they increased by more than 4 million homes (data: Palmer and Cooper 2013), there has not been an increase in the consumption of hard coal in British households. Relative to 1990, the consumption of hard coal in Britain's residential sector decreased by $88 \%$ (Fig. $8 \mathrm{~b}$ and Fig. 9b) and in 2014 fell to 0.3 million toe. With regard to the EU28 area, the share of this fuel's consumption decreased from 19 to $4 \%$. The main source of energy used by British households is natural gas (Fig. 9b): in 1990 and 2014, its share was at a similar level of $62 \%$ and $61 \%$ (ie. 21.5 and 23.2 million toe). Electricity was second, and its share rose from 22 to $27 \%$ (from 8.1 to 9.4 million toe). Renewable energy sources ranked third, the consumption of which increased from 2.1 to 2.8 million toe.

Several factors contributed to the decrease in hard coal consumption by the customers of the British residential sector. Apart from the environmental factor described in an earlier chapter, there has also been an increase in the number of dwellings with central heating system: in 1990, 72\% of British housing stock (data: Palmer and Cooper 2013) were equipped with central heating (16.8 million pcs.), while in 2011 their share increased to $91 \%$ (nearly 25.0 million pes.). In most apartments, central heating boilers are fed with gas: in 1990 the share of dwellings using gas fuel was $83 \%$, and in 2011 the share increased by 10 percentage points (data: Palmer and Cooper 2013). The share of homes using solid fuels fell from $8 \%$ (in 1990) to 1\% (2014). The number of furnaces for solid fuels (not forming part of a central heating system) decreased almost 17 times and in 2011 was only 52 thousand pcs.

For years, the United Kingdom has been known as a country fighting against low emissions. Until the 1950s, the main source of air pollution apart from industrial emission was burning coal in boilers and domestic fireplaces. In London alone, eight episodes of severe air pollution were recorded between 1948 and 1962 (Air quality... 2002). The heaviest - called The Great Smog - occurred in December 1952, when the degree of air pollution in relation 
to the level accepted as "normal" was exceeded by as much as 56 times. Fearing for human health, a law called The Clean Air Act was passed in 1956, which first introduced the "smoke control areas", mainly from the combustion of coal. As a result, since the 1960s, an increase in the consumption of so-called cleaner fuels - particularly natural gas - has been observed. For example, the consumption of natural gas for heating purposes in central heating systems increased (data Palmer and Cooper 2013) from 1.98 in 1970 up to 22.98 million dwellings in 2011.

\section{Summary}

The case of the United Kingdom can serve as a reference point for hard coal consumption in households in Poland. There is an active coal mining industry in both of the compared countries, which is also related to adherence to the use of domestic resources in households. In the UK, the coal industry is already in a declining phase, while in Poland subsequent attempts for restructuring have been made. The consequence of the gradual closure of mines will be the reduction in the availability of domestic resources on the Polish market, which can be replaced by imports.

In the UK, The Clean Air Act was adopted as early as in 1956, while in Poland - the so-called anti-smog law, which is an amendment to the Environment Protection Law, was adopted in 2015 (Ustawa... 2015). According to the anti-smog act, the decision to restrict or ban the use of installations burning solid fuels is made by the province parliament in the form of resolution, which is then presented to the competent local commune heads, mayors or presidents of cities and starosts to get their opinions.

It should be noted that in the UK, the substitution of coal with other fuel - mainly natural gas - was not a quick process, and lasted for several decades. In addition, domestic coal was replaced with another mainly domestic resource - natural gas. This ensured the security of gas supply, and - unlike in Poland - has not forced dependence on exporting countries and negotiated prices.

When considering the use of different energy carriers, one should also take the financial aspect into account: according to (Jurdziak 2012) the vast majority of households in Poland is threatened by energy poverty. Very often the economic factor determines the choice of energy carrier. According to the data (GUS - Zużycie energii... 2014), the analysis of annual expenditures for heating one $\mathrm{m}^{2}$ of usable space with hard coal and high-methane gas, the former generates lower costs. In relation to high-methane natural gas they were lower by $9 \mathrm{PLN} / \mathrm{m}^{2}$ (data for 2012) and reached $23 \mathrm{PLN} / \mathrm{m}^{2}$ of usable space.

As of 2020, Poland will apply European standards for the marketing and use of low-power solid fuel boilers. These boilers are generally dedicated to fuels with specified quality parameters. Burning good quality coal or qualified carbonaceous fuels while applying high-efficiency, low-emission boilers can greatly reduce the negative effects of burning hard coal on the environment. 
Publication prepared within the statutory research of The Mineral and Energy Economy Research Institute, Polish Academy of Sciences.

\section{LITERATURA}

Blaschke red. 2003 - Blaschke, W. 2003. Funkcjonowanie górnictwa węgla kamiennego na podstawie uregulowań prawnych Unii Europejskiej w latach 1993-2002. Studia, Rozprawy, Monografie nr 122. Kraków: Wyd. IGSMiE PAN, 75 pp. (in Polish).

Gawlik, L. red. 2013. Węgiel dla polskiej energetyki w perspektywie 2050 roku-analizy scenariuszowe. Górnicza Izba Przemysłowo-Handlowa. Katowice: Wyd. IGSMiE PAN, 299 pp. (in Polish).

Grudziński, Z. 2012. Sytuacja na giełdach handlu emisją a ceny energii elektrycznej. Polityka Energetyczna - Energy Policy Journal t. 15, z. 3. Kraków: Wyd. IGSMiE PAN, pp. 77-90 (in Polish).

Grudziński, Z. 2013. Koszty środowiskowe wynikające z użytkowania węgla kamiennego w energetyce zawodowej. Annual Set the Environment Protection-Rocznik Ochrona Środowiska Vol. 15, pp. 2249-2266, (in Polish).

Jurdziak, L. 2012. Czy grozi nam ubóstwo? Analiza potencjalnych skutków unijnej polityki walki z globalnym ociepleniem dla gospodarstw domowych w Polsce. Polityka Energetyczna-Energy Policy Journal t. 15, z. 3. Kraków: Wyd. IGSMiE PAN, pp. 23-50 (in Polish).

Kamiński, J. 2014. A blocked takeover in the Polish power sector. A model based analysis. Energy Policy Vol. 66 pp. $42-52$.

Klojzy-Karczmarczyk, B. and Mazurek, J. 2009. Zadania samorządów lokalnych w procesie likwidacji niskiej emisji. Polityka Energetyczna - Energy Policy Journal t. 12, z. 2/2, pp. 277-284 (in Polish).

Klojzy-Karczmarczyk, B. and Mazurek, J. 2013. Studies of mercury content in selected coal seams of the Upper Silesian Coal Basin. Gospodarka Surowcami Mineralnymi-Mineral Resources Management Vol. 29, Is. 4, pp. 95-106.

Kubica, K. 2013. Instalacje spalania małej mocy na paliwa stałe - węgiel, biomasę. Możliwości wykorzystania SCIs w ramach Programu Priorytetowego nt. „Likwidacja niskiej emisji poprzez wzrost efektywności energetycznej i rozwój odnawialnych źródeł energii” oraz dalszych prac nad Krajowym Programem Ochrony Powietrza. Opracowanie, Platforma Urządzeń Grzewczych na Paliwa stałe Polska Izba Ekologii, Katowice, lipiec 2013, s. 22. [Online] Available at: (http://www.pie.pl/materialy/_upload/flash/Stan_techniki_SCIs_PropSPUGPS_31072013.pdf) [Accessed: 21.06.2016] (in Polish).

Kubica, K. 2015. Kotły opalane paliwami stałymi - uregulowania europejskie od 2020 roku. Niezły węgiel. Magazyn Instalatora 3(199), pp. 32-33 (in Polish).

Mudgal et al. 2009 - Mudgal, S., Turbe, A., Kuwahara, I., Stewart, R., Woodfield, M., Kubica, K. and Kubica , R. 2009. Preparatory Studies for Eco-design Requirements of EuPs (II). Lot 15 Solid fuel small combustion installations. Task 1: Scope and Definition. Final version. (Contract NoTREN/D3/390-2006/Lot15/2007/ S07.74922). European Commission - DG TREN, 116 pp.

Lorenz, U. 1999. Metody oceny wartości węgla kamiennego energetycznego uwzględniająca skutki jego spalania dla środowiska przyrodniczego. Studia, Rozprawy, Monografie nr 64. Kraków: Wyd. IGSMiE PAN, 84 pp. (in Polish).

Olkuski T., 2013 - Sposoby poprawy negatywnego skutku oddziaływania węgla na środowisko przyrodnicze poprzez stosowanie alternatywnych metod jego wykorzystania. Annual Set the Environment Protection -Rocznik Ochrona Środowiska Vol. 15, pp. 1474-1488 (in Polish).

Palmer, J. and Cooper, I. 2013. United Kingdom housing energy fact file: 2013. Department of Energy \& Climate Change, Prepared under contract to DECC by Cambridge Architectural Research, Eclipse Research Consultants and Cambridge Energy. The views expressed are not necessarily DECC's. p. 172. [Online] Available at: (https://www.gov.uk/government/uploads/system/uploads/attachment_data/file/345141/uk_housing_fact_ file_2013.pdf) [Accessed: 21.06.2016]

Pawul, M. and Sobczyk, W. 2011. Edukacja ekologiczna w zakresie gospodarki odpadami jako narzędzie realizacji zrównoważonego rozwoju. Problems of sustainable development Vol. 6, No 1, pp. 147-156 (in Polish). 
Pittini et al. 2015 - Pittini, A., Ghekière, L., Dijol, J. and Kiss, I. 2015. The State of Housing in the EU 2015. A Housing Europe Review. The European Federation for Public, Cooperative and Social Housing, Brussels, 106 p. [Online] Available at: (http://www.housingeurope.eu/event-447/the-state-of-housing-in-the-eu-2015) [Accessed: 09.05.2016].

Szczerbowski, R. 2015. Polityka energetyczna wybranych krajów europejskich a strategia energetyczna Polski. Polityka Energetyczna - Energy Policy Journal t. 18, z. 3. Kraków: Wyd. IGSMiE PAN, pp. 5-14 (in Polish).

Eurostat Complete... - Eurostat: Complete Energy balances - annual data. [Online] Available at: (http://ec.europa.eu/eurostat/) [Accessed: 09.05.2016].

Eurostat - Economy... - Eurostat - Economy and Finance GDP and main components. [Online] Available at: (http://ec.europa.eu/eurostat/) [Accessed: 09.05.2016].

Eurostat - Distribution... - Eurostat - Distribution of population by degree of urbanization, dwelling type and income group. [Online] Available at: (http://ec.europa.eu/eurostat/) [Accessed: 12.05.2016].

Eurostat - Glossary... - Eurostat - Glossary: Revision of the degree of urbanisation. [Online] Available at: (http://ec.europa.eu/eurostat/) [Accessed: 09.05.2016].

Eurostat - Housing... - Eurostat - Housing condition: Distribution of population by degree of urbanization, dwelling type and income group. [Online] Available at: (http://ec.europa.eu/eurostat/) [Accessed: 09.05.2016].

Eurostat - Population... - Eurostat - Population and social condition (Population on 1 January). [Online] Available at: (http://ec.europa.eu/eurostat/) [Accessed: 09.05.2016].

Eurostat - Relationships... Eurostat - Relationships between products and flows of Energy Balances. Eurostat. [Online] Available at: (http://ec.europa.eu/eurostat/) [Accessed: 09.05.2016].

GUS - BDL - Bank Danych Lokalnych. Bazy danych GUS. [Online] Available at: (www.stat.gov.pl [Accessed: 21.06.2016] (in Polish).

GUS - Rocznik statystyczny...1991-2015 - Rocznik Statystyczny Rzeczypospolitej Polskiej. Warszawa: Wyd. GUS, wydania z lat 1991-2015 (in Polish).

GUS - Zużycie energii... 2012 - Zużycie energii w gospodarstwach domowych w 2009 r. Warszawa: Wyd. GUS, 136 pp. (in Polish)

GUS - Zużycie energii... 2014 - Zużycie energii w gospodarstwach domowych w 2012 r. Warszawa: Wyd. GUS, 158 pp. (in Polish)

GUS - Warunki... 2003 - Warunki mieszkaniowe gospodarstw domowych i rodzin 2002. Warszawa: Wyd. GUS, 2013, pp. (in Polish).

GUS - Warunki... 2014 - Warunki mieszkaniowe gospodarstw domowych i rodzin - NSP 2011 - wyniki (dane tabelaryczne w plikach .xlsx) (in Polish).

Implementacja prawa... 2013 - Implementacja prawa klimatyczno-energetycznego UE w Polsce. Fundacja Client Earth Poland, Warszawa 2013, 102 s., ISBN 978-83-938296-0-6. [Online] Available at:

(http://www.clientearth.org/reports/implementacja-prawa-klimatyczno-energetycznego-ue-w-polsce.pdf) [Accessed: 12.05.2016] (in Polish).

Air quality... 2002 - Air quality in the UK. Parliament Office of Science and Technology, London, Postnote, November 2002 Number 188, p. 4. [Online] Available at: (http://www.parliament.uk/documents/post/pn188.pdf)) [Accessed: 12.05.2016].

Council Decision 2002/358/EC - Council Decision 2002/358/EC of 25 April 2002 concerning the approval, on behalf of the European Community, of the Kyoto Protocol to the United Nations Framework Convention on Climate Change and the joint fulfilment of commitments thereunder. OJ L 130 of 15.5.2002. [Online] Available at: (http://eur-lex.europa.eu/) [Accessed: 21.06.2016].

Council Decision 91/565/EEC - 91/565/EEC: Council Decision of 29 October 1991 concerning the promotion of energy efficiency in the Community (SAVE programme). OJ L 307, 8.11.1991, pp. 34-36. [Online] Available at: (http://eur-lex.europa.eu/) [Accessed: 21.06.2016].

Commission Decision 2006/944/EC - Commission Decision 2006/944/EC of 14 December 2006 determining the respective emission levels allocated to the Community and each of its Member States under the Kyoto Protocol pursuant to Council Decision 2002/358/EC (notified under document number C(2006) 6468) (2006/944/EC). [Online] Available at: (http://eur-lex.europa.eu/) [Accessed: 21.06.2016] 
Commission Decision 2010/778/EU - 2010/778/EU: Commission Decision of 15 December 2010 amending Decision 2006/944/EC determining the respective emission levels allocated to the Community and each of its Member States under the Kyoto Protocol pursuant to Council Decision 2002/358/EC (notified under document C(2010) 9009). [Online] Available at: (http://eur-lex.europa.eu/) [Accessed: 21.06.2016].

Council Directive 2013/12/EU - Council Directive 2013/12/EU of 13 May 2013 adapting Directive 2012/27/EU of the European Parliament and of the Council on energy efficiency, by reason of the accession of the Republic of Croatia. OJ L 141, 28.5.2013, pp. 28-29. [Online] Available at: (http://eur-lex.europa.eu/) [Accessed: 21.06.2016].

Council Directive (96/61/EC) - Council Directive 96/61/EC of 24 September 1996 concerning integrated pollution prevention and control. OJ L 257, 10.10.1996, pp. 26-40. [Online] Available at: (http://eur-lex.europa.eu/) [Accessed: 21.06.2016].

COM(2001)0245 - Communication from the Commission - The Clean Air for Europe (CAFE) Programme: Towards a Thematic Strategy for Air Quality /* COM/2001/0245 final */. [Online] Available at: (http://eur-lex.europa.eu/) [Accessed: 21.06.2016].

$\operatorname{COM}(2005) 446$ final - Communication from the Commission to the Council and the European Parliament. Thematic Strategy on air pollution. Brussels, 21.9.2005. [Online] Available at: (http://eur-lex.europa.eu/) [Accessed: 21.06.2016].

$\operatorname{COM}(2008) 30$ final - Communication from the Commission to the European Parliament, the Council, the European Economic and Social Committee and the Committee of the Regions - 2020 by 2020 - Europe's climate change opportunity $\{\mathrm{COM}(2008) 13$ final $\}\{\mathrm{COM}(2008) 16$ final $\}\{\mathrm{COM}(2008) 17$ final $\}$ \{COM(2008) 18 final $\}$ $\{\mathrm{COM}(2008) 19 \mathrm{final}\}$. [Online] Available at: (http://eur-lex.europa.eu/) [Accessed: 21.06.2016].

COM(2014) 15 final - Communication from the Commission to the European Parliament, the Council, the European Economic and Social Committee and the Committee of the Regions A policy framework for climate and energy in the period from 2020 to $2030 / *$ COM/2014/015 final */. [Online] Available at: (http://eur-lex.europa.eu/) [Accessed: 21.06.2016].

Commission Regulation 2015/1189 - Commission Regulation (EU) 2015/1189 of 28 April 2015 implementing Directive 2009/125/EC of the European Parliament and of the Council with regard to ecodesign requirements for solid fuel boilers (Text with EEA relevance). OJ L 193, 21.7.2015, pp. 100-114. [Online] Available at: (http://eur-lex.europa.eu/) [Accessed: 21.06.2016].

Directive 2008/50/EC - Directive 2008/50/EC of the European Parliament and of the Council of 21 May 2008 on ambient air quality and cleaner air for Europe. [Online] Available at: (http://eur-lex.europa.eu/) [Accessed: 21.06.2016]

Directive 2012/27/EU - Directive 2012/27/EU of the European Parliament and of the Council of 25 October 2012 on energy efficiency, amending Directives 2009/125/EC and 2010/30/EU and repealing Directives 2004/8/EC and 2006/32/EC Text with EEA relevance. OJ L 315, 14.11.2012, pp. 1-56. [Online] Available at: (http://eur-lex.europa.eu/) [Accessed: 21.06.2016].

PN-EN 303-5:2012 - Kotły grzewcze - Część 5: Kotły grzewcze na paliwa stałe z ręcznym i automatycznym zasypem paliwa o mocy nominalnej do $500 \mathrm{~kW}$ - Terminologia, wymagania, badania i oznakowanie (in Polish).

Programme Europe... - Europe 2020. [Online] Available at: (http://ec.europa.eu/europe2020/index_en.htm) [Accessed: 21.06 .2016$]$

Ustawa... 2015 - Ustawa z dnia 10 września 2015 r. o zmianie ustawy - Prawo ochrony środowiska. Dz.U. 2015 poz. 1593. Tekst ogłoszony. [Online] Available at: (www.isap.sejm.gov.pl) [Accessed: 21.06.2016] (in Polish).

TENDENCJE ZMIAN ZUŻYCIA WĘGLA KAMIENNEGO W GOSPODARSTWACH DOMOWYCH POLSKI NA TLE UE

\author{
Słowa kluczowe
}

Węgiel kamienny, gospodarstwa domowe, zużycie, podaż, Polska, UE 


\section{Streszczenie}

Z uwagi na istotną rolę, jaką w polskim sektorze mieszkaniowym odgrywa węgiel kamienny, w artykule prześledzono zmiany, jakie nastąpiły w zużyciu tego paliwa w Unii Europejskiej oraz w Polsce w latach 1990-2014.

Na całym obszarze Unii Europejskiej węgiel kamienny zajmuje istotne miejsce w strukturze zużycia energii pierwotnej. W latach 1990-2014 zużycie energii pierwotnej w UE (w przeliczeniu dla wszystkich 28 państw członkowskich) zmieniało się od 1507 do $1722 \mathrm{mln}$ toe. Pomiędzy rokiem 2014 a 1990 zanotowano spadek zużycia energii pierwotnej, a średnioroczne tempo spadku wyniosło -0,2\%. Według Council Directive 2013/12/EU do roku 2020 zużycie energii w całej Unii ma wynieść nie więcej niż $1483 \mathrm{mln}$ toe energii pierwotnej, a już w 2014 r. łączne zużycie energii pierwotnej w UE28 było wyższe od założonego celu jedynie o $24 \mathrm{mln}$ toe (2\%).

Podejmowane działania na rzecz ochrony klimatu skutkują zmniejszeniem zużycia węgla kamiennego w Unii Europejskiej. Pomiędzy rokiem 1990 a 2014 zużycie węgla kamiennego zmniejszyło się o $41 \%$ (spadek o $126 \mathrm{mln}$ toe), a średnioroczne tempo spadku zużycia tego paliwa wyniosło $-2,1 \%$.

$\mathrm{Na}$ całym obszarze Wspólnoty gospodarstwa domowe nie są tak istotnym konsumentem węgla kamiennego, jak w Polsce. Chociaż w UE28 zużycie węgla w tym sektorze w latach 1990-2014 zmieniało się w zakresie $6,5-15,8 \mathrm{mln}$ toe, to jego udział w ogólnym zużyciu tego paliwa najczęściej utrzymywał się na poziomie około $3-5 \%$.

Zmieniający się miks paliwowy, zamykanie kopalń lub stopniowe wygaszanie górnictwa węgla kamiennego oraz polityka środowiskowa danego państwa spowodowały, że w części państw unijnych surowiec ten stracił swoją pozycję.

Analizując strukturę zużycia węgla kamiennego przez gospodarstwa domowe w krajach UE28 zauważamy, że w latach 1900-2014 czołówkę stanowiły te państwa, które posiadały własne kopalnie węgla. Ze względu na strukturę zużycia węgla kamiennego przez tę grupę odbiorców, w artykule szerzej omówiono dwa państwa: Polskę i Wielką Brytanię. W roku 1990 stanowiły ścisłą czołówkę: Polska (50\%) i Wielka Brytania (18\%), a dwadzieścia pięć lat później tylko Polska pozostała na pierwszym miejscu (84\%), a Wielka Brytania spadła na miejsce czwarte (4\%).

Pomiędzy rokiem 2014 a 1990 zużycie węgla kamiennego przez brytyjski sektor mieszkaniowy zmniejszyło się o $88 \%$ i spadło do $0,3 \mathrm{mln}$ toe. W przypadku Polski co prawda zmalało o $6 \%$, ale nadal przekraczało 6 mln toe. Spadek zużycia węgla kamiennego w Wielkiej Brytanii był w dużej mierze konsekwencją wprowadzonej w 1956 r. ustawy The Clean Air Act. W Wielkiej Brytanii proces zastępowania węgla innym paliwem (głównie gazem ziemnym) trwał kilka dziesięcioleci. Rodzimy węgiel zastępowany był w głównej mierze również rodzimym gazem, co zapewniało bezpieczeństwo jego dostaw.

W artykule scharakteryzowano także gospodarstwa domowe w Unii Europejskiej oraz w Polsce. Wzięto pod uwagę ogólną bazę zasobową mieszkań, jak również podział populacji według stopnia urbanizacji. Omówiono również uregulowania prawne, które w istotny sposób wpływają na zużycie nośników energii w Unii Europejskiej. 
TRENDS IN THE CONSUMPTION OF HARD COAL IN POLISH HOUSEHOLDS COMPARED TO EU

\author{
Keywords
}

Hard coal, households, consumption, supply, Poland, EU

Abstract

Due to the important role of hard coal in the Polish residential sector, the article traced the changes that have occurred in the use of this fuel in the European Union and in Poland in the years 1990-2014.

Throughout the European Union, hard coal has an important place in the structure of primary energy consumption. In the years 1990-2014, primary energy consumption in the European Union (calculated for all 28 Member States) has changed between 1507 and 1722 million toe. Between 2014 and 1990, there was a decrease of primary energy consumption, and the average rate of decline amounted to $-0.2 \%$. According to Council Directive 2013/12/EU, by the year 2020 energy consumption throughout the EU is expected to be no more than 1483 Mtoe of primary energy, and already in 2014 total primary energy consumption in the EU28 was higher than assumed by this target by only about 24 million toe $(2 \%)$.

Actions taken to protect the climate result in reducing the consumption of hard coal in the European Union. Between 1990 and 2014, the consumption of hard coal decreased by 41\% (a decrease of 126 million toe), and the average rate of decline in consumption of this fuel amounted to $-2.1 \%$.

Throughout the EU, households are not as significant a consumer of hard coal, as in Poland. Although EU28's coal consumption in this sector in the years 1990 to 2014 varied between 6.5-15.8 million toe, its share in the overall consumption of this fuel usually maintained at around 3-5\%.

The changing fuel mix, closing of mines or gradual extinction of coal mining, environmental policy of the individual countries meant that coal has lost its position in some of them.

Analyzing the structure of hard coal consumption by households in the EU28 countries in the years 1900 to 2014, one may notice that the leaders are those countries that have their own coal mines. Due to the structure of consumption of hard coal by the customers, the article discussed two countries: Poland and Great Britain in greater detail. In 1990, Poland (50\%) and Britain (18\%) were close leaders, and twenty-five years later, only Poland has remained in first place (84\%) and Great Britain has fallen to fourth place $(4 \%)$.

Between 2014 and 1990, the consumption of hard coal by the British residential sector decreased by $88 \%$ to only 0.3 million toe. In the case of Poland, it admittedly decreased by $6 \%$, but still exceeds 6 million toe. The decrease in hard coal consumption in Great Britain was largely a consequence of The Clean Air Act introduced in 1956. In Britain, the process of replacing coal with other fuels (mostly natural gas) lasted several decades. Domestic coal was replaced with another mainly domestic resource - natural gas which ensured the security of its supply.

The article also describes the households in the European Union and in Poland. The overall housing stock was taken into account, together with the distribution of population according to the degree of urbanization. Regulations that have a significant impact on the consumption of energy in the European Union were also discussed. 